\title{
ERRORS BEHIND ASKING OPEN-ENDED QUESTIONS: A STUDY IN INDIVIDUAL COUNSELING CLASS
}

\author{
Yeni Afrida \\ State Islamic Institute of Bukittinggi, Indonesia \\ E-mail: yeniafrida664@gmail.com \\ Fadhilla Yusri \\ State Islamic Institute of Bukittinggi, Indonesia \\ E-mail: fadbillayusri@gmail.com
}

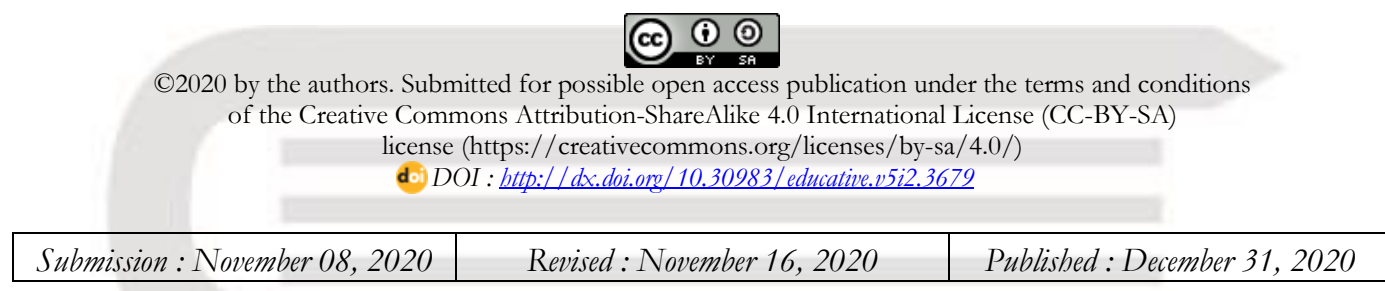

\begin{abstract}
The skill of asking open-ended questions is one of the most important skills in counseling. Asking the right questions may help a counselor to understand the counselee's situation. This study aims to reveal the errors in asking open-ended questions during the implementation of individual counseling conducted by 27 fourth-semester students of the Guidance and Counseling Study Program, Faculty of Tarbiyah and Teaching Training, State Islamic Institute (IAIN) Bukittinggi. The research was conducted through a quantitative approach. This research found that there were some common errors made by students when using open-ended questions; they were 1) $70.37 \%$ of students used openended questions that were not coherent, 2) $66 \%$ of students used open-ended questions "why" in their question, 3) 40.74\% used repeated open-ended questions that have the same meaning, 4) $29.62 \%$ used open-ended questions that did not in line with the context, 5) $14.81 \%$ students used open-tailed questions, 6) $11.11 \%$ students used 2 open-ended questions simultaneously at the same time, and 7) there were $11.11 \%$ who did not use open-ended questions at all during the counseling process.
\end{abstract}

Keywords: open-ended question, skill, counseling.

\section{Abstrak}

Bertanya adalah salah satu keterampilan yang paling penting dalam proses konseling. Pengajuan pertanyaan-pertanyaan yang tepat dapat membantu konselor memabami situasi konseli, alasan konseli menemui konselor, harapan-harapan konseli, dan informasi-informasi yang relevan dengan situasi yang dibadapi oleh konseli saat itu. Keterampilan menggunakan pertanyaan terbuka merupakan salab satu dari keterampilan bertanya yang penting tersebut. Penelitian ini berupaya mengungkapkan pertanyaan-pertanyaan terbuka yang digunakan oleh 27 orang mahasiswa semester IV Program Studi Bimbingan dan Konseling Institut Agama Islam Negeri Bukittinggi dalam pelaksanaan konseling individual. Secara spesifik penelitian ini bertujuan untuk mengungkapkan kesalahan-kesalahan penggunaan pertanyaan terbuka dalam konseling individual yang dilakukan oleh mahasiswa. Penelitian dilakukan melalui pendekatan kuantitatif. Melalui penelitian ini diperoleh informasi bahwa, terdapat beberapa kesalahan umum yang dilakukan mahasiswa pada saat menggunakan pertanyaan terbuka yaitu 1) 70,37\% mahasiswa menggunakan pertanyaan terbuka yang tidak runtut, 2) 66\% mahasiswa menggunakan pertanyaan terbuka dengan kata tanya mengapa, 3) 40,74\% menggunakan pertanyaan terbuka yang berulang dengan makna sama, 4) 29,62 \% menggunakan pertanyaan terbuka yang tidak sesuai konteks, 5) 14,81\% mahasiswa menggunakan pertanyaan terbuka mengekor, 6) 11,11\% mahasiswa menggunakan sekaligus 2 pertanyaan terbuka dalam waktu yang sama, dan 7) terdapat 11,11 persen yang sama sekali tidak. mengounakan pertanyaan terbuka selama proses konseling.

Kata kunci: pertanyaan terbuka, keterampilan, konseling 


\section{Introduction}

One of the counselor's main tasks is to help the counselee resolve and manage his/her mental issues. Because of this helpful aspect in counseling, Ray Collledge, one of the counseling experts, even simply defines counseling as a helping relationship. as "a helping relationship" counseling requires variety of basic skills that the counselor inevitably has to master. ${ }^{123456}$ Asking in this regard is said to be one of the most essential skills in the counseling process. ${ }^{7891011}$ After all, counseling is essentially the occurrence of

1 Colledge. Ray, Mastering Counseling Theory (Newyork: Palgrave Macmillan, 2002), p. 1.

2 Rosie March-Smith, Counselling Skills for Complementary Therapists (England: Open University Press, 2005), p. 1.

${ }^{3}$ Melanie M Larussi and others, "Outcomes of Incorporating Motivational Interviewing into Basic Counselor Skills Training," The Journal of Counselor Preparation and Supervision, 12.1 (2019), p. 1-26 $<$ https://repository.wcsu.edu/jcps/vol12/iss1/4>.

4 Arbin Janu Setiyowati and others, "Structural Model of Counseling Competence," Cakrawala Pendidikan, $38.1 \quad$ (2019), p. 45-62 <https://doi.org/10.21831/cp.v38i1.21509>.

5 Nova ErlinaYaumas and others, "The Importance of Counselling Basic Skills for the Counsellors," International Journal of Pure and Applied Mathematics, 119.July 2019 (2018), p. 1195-1207.

6 Clara E. Hill and others, "Helping Skills Training for Undergraduates: Outcomes and Prediction of Outcomes.," Journal of Counseling Psychology, 55.3 (2008), p. 359-370 <https://doi.org/10.1037/00220167.55.3.359>.

Carlos P. Zalaquet Allen E. Ivey, Mary Bradford Ivey, Intentional Interviewing and Counseling: Facilitating Client Development in a Multicultural Society, 9th edn (Cengage Learning, 2013), p. 1.

${ }^{8}$ Patricia McCarthy Veach, Bonnie S. LeRoy, and Nancy P. Callanan, "Gathering Information: Asking Questions," in Facilitating the Genetic Counseling Process (Cham: Springer International Publishing, 2018), p. 111-137 <https://doi.org/10.1007/978-3-31974799-6_5>.

9 Syamsu Yusuf, "Karakteristik, Kompetensi Dan Peran Konselor,” 2020.

${ }^{10}$ Sally Aldridge and Sally Rigby, Counselling Skills in Context (UK: British Association for Counselling and Psychotherapy (BACP), 2001), p. 25-28.

11 Ian Andrew James, Rachel Morse, and Alan Howarth, "The Science and Art of Asking Questions in Cognitive Therapy," Behavioural and Cognitive Psychotherapy, $38.1 \quad$ (2010), p. 83-93 $<$ https://doi.org/10.1017/S135246580999049X>. communication between counselor and counselee, while communication requires the counselor's skill in asking questions. ${ }^{121314}$

Mastery of questioning skills can help the counselor to reveal important information related to the counselee in the counseling process. It is said that "Questioning is an important part of counseling. It helps us understand the client's situation and it helps us assess clinical conditions. Questions during the counseling session can help to open new areas for discussion. They can assist to pinpoint an issue and they can assist to clarify information that at first may seem ambiguous to the counselor". ${ }^{15}$ It is not an exaggeration to say that asking questions is the primary tool in counseling as mentioned by Darren and Joshua "Questions are the primary tool counselors utilize to learn about their client's experiences. ${ }^{16}$

Also, the need for specific information about the counselee in the counseling process is another strong reason for mastering questioning skills. Rationally, the counselor may have detailed information about the counselee if the counselor is eager to ask

12 Gibson and Mitchell, Bimbingan Dan Konseling (Yudi Santoso: Terj). (Yogyakarta: Pustaka Pelajar, 2011). p.247

13 Afonso Cavaco, "Pharmaceutical Care and Patient Counseling," in The Pharmacist Guide to Implementing Pharmaceutical Care (Cham: Springer International Publishing, 2019), pp. 33-40 <https://doi.org/10.1007/978-3-319-92576-9_4>.

14 D. Ridley, C. R., Kelly, S. M., \& Mollen, "Microskills Training: Evolution, Reexamination, and Call for Reform," The Counseling Psychologist, 39.6 (2011), p. $\quad 800-824$ <https://doi.org/https://journals.sagepub.com/doi/1 $0.1177 / 0011000010378438>$

15 Syed Muhammad and Sajjad Kabir, "Topics Covered Active Listening Verbal and Non-Verbal Messages Attending Responding Paraphrasing Summarizing Ask Questions Probing," 2018.

16 Darren A Wozny and Joshua C Watson, “Counselors' Questioning Skills Repertoire: What We Use and What We Don't.," VISTAS Online, 2006, 139_ $142<$ http://www.counseling.org/docs/defaultsource/vistas/counselors-questioning-skills-repertoirewhat-we-use-and-what-we-dont.pdf?sfvrsn $=10>$. 
directly to the counselee. Furthermore, the counselor cannot offer appropriate assistance to the counselee if the counselor does not fully understand the detailed information about the counselee. The ability to ask questions is needed to obtain information about the counselee and this information is needed so that the counselor can help the counselee optimally. It can be said that the counselor will never be able to help the counselee optimally if the counselor is not a master in asking questions. It is said that" We need specific information and feedback from the client to help them, so being able to ask good questions is an essential skill for as skilled helper". ${ }^{17}$ High quality and low-quality counseling, one of which can even be assessed from the questions used by the counselor during the counseling session. ${ }^{18}$

Besides that, questioning skills are also important for several reasons. Yeo explains that the right questions can smooth the flow of the conversation between the counselor and the counselee. He also explains that the use of questions can effectively help the counselor initiate the counseling conversation. Moreover, the use of questions can effectively help in uncovering areas of discussion. Furthermore, Yeo gues that the use of questions effectively can help the counselor in sharpening the counselee's problems. He adds that the use of questions can also effectively help the counselor to have a better understanding of the counselee's situation while also can effectively help the counselee to tell the problem clearly and directed. The

${ }^{17}$ Lesli E Borck, Learning Counseling and Problem Solving Skilss (Newyork: The Haworth Press, 1982), p. 1.

18 Verónica Pérez-Rosas and others, "Analyzing the Quality of Counseling Conversations: The Tell-Tale Signs of High-Quality Counseling," in LREC 2018 11th International Conference on Language Resources and Evaluation, 2019, p. 3742-3748. questioning skills include the skills to use open-ended questions. ${ }^{1920212223242526}$

It is said that "Effective counselors can encourage counselees to have the courage to talk about their problems, to be open and willing to be helped. This can be realized when the counselor has additional skills, such as being able to use open-ended questions, being able to reflect feelings, being able to focus on problems, and being able to show a general interest in the counselee and his problems". ${ }^{27}$ Besides, there is nothing more beneficial to the problem exploration process in the counseling process than the proper use of open-ended questions. It is said that "The questions that best assist the process of exploring are those with open up possibilities,

19 Anthony Yeo, Konseling: Suatu Pendekatan Pemecahan Masalah (Antonius Wuisan, Terj) (Jakarta: Gunung Mulia, 2007), p. 1.

20 Kevin J Drab, "The Top Ten Basic Counseling Skills,” 2015, p. 1-3 $<$ https://www.people.vcu.edu/ krhall/resources/cnsls kills.pdf $>$.

21 Cormier, Interviewing and Change Strategies for Helpers: Fundamentals Skills and Cognitive Behavioral Interventions (California: Brooks/ Cole, 2009), p. 1.

22 Bakkar S Bakkar, "The Effect of a Counseling Microskills Course on the Mastery Level of Communication Skills among Omani Career Counselors The Effect of a Counseling Microskills Course on the Mastery Level of Communication Skills among Omani Career Counselors," 14.January 2012 (2019), p. 44-56.

${ }^{23}$ Michael J. Tanana and others, "Development and Evaluation of Clientbot: Patient-like Conversational Agent to Train Basic Counseling Skills," Journal of Medical Internet Research, 21.7 (2019), p. 1-13 $<$ https://doi.org/10.2196/12529>.

24 Rebecca L. Koltz and Stephen S. Feit, "A Phenomenological Study: The Experience of Live Supervision during a Pre-Practicum Counseling Techniques Course," Qualitative Report, 17.40 (2012), p. $1-24$.

25 Erik Rautalinko, "Reflective Listening and Open-Ended Questions in Counselling: Preferences Moderated by Social Skills and Cognitive Ability," Counselling and Psychotherapy Research, 13.1 (2013), p. 24 31 <https://doi.org/10.1080/14733145.2012.687387>.

${ }^{26}$ Rayane AbuSabha, "Interviewing Clients and Patients: Improving the Skill of Asking Open-Ended Questions," Journal of the Academy of Nutrition and Dietetics, $113.5 \quad$ (2013), p. 624-633 <https://doi.org/10.1016/j.jand.2013.01.002>.

27 Yeo, p. 1. 
rather than closing them off" ${ }^{28}$ Therefore, it is highly recommended to use open-ended questions in counseling. ${ }^{29}$

Open-ended questions are defined as those that cannot be answered in a few words, they encourage the client to speak and offer an opportunity for the counselor to gather information about the client and their concerns. ${ }^{30}$ In other words, the expected result of using open-ended questions is long and informative answers about the counselee. The use of open-ended questions also encourages the counselee to talk more and be able to express his thoughts and feelings more freely. On contrary, the same thing is certainly not found when the counselor chooses to use closed questions. It is said that "The use of closed-ended questions that too often will limit the counselee and hinder the course of the conversation. Closed-ended questions are only used when the counselor wants to get information, clarity, and focus and directs the counselee on a specific problem ". ${ }^{31}$

In conducting the counseling, openended questions are one of the most frequently used (although not used exclusively) techniques during a counseling session. Therefore, professional counselors and therapists are usually trained for and trained in using open-ended questions. In a stronger argument, it can be said that the use of openended questions in the counseling process, as previously mentioned, allows the disclosure of detailed information about the counselee. In addition, open-ended questions can indirectly motivate the counselee to share relevant

28 Penny Gardner Hugh Crago, A Safe Place for Change, Revised 2nd Edition: Skills and Capacities for Counseling and Therapy, revised 2n (Australia: Australia: digital publishing centre an imprinting interactive publication Brisbane, 2019), p. 1.

${ }^{29}$ Yusuf.

$30 \mathrm{D}$ Evans, $\mathrm{M}$ Hearn, and $\mathrm{M}$ Uhlemann, "Counselling Micro Skills," Essential Interviewing: $A$ Programmed Approach to Effective Communication, 1998, p. $156-157$.

31 Yeo, p. 1. information about his life, his way of thinking, his perception of something, his beliefs, and so on. Instead of using closed-ended questions that require only a "yes or no" answer, professional counselors and therapists usually prefer to use open-ended questions.

Consider the following two questions: 1) Do you like it? and 2) How do you feel about it? The two questions have the same essence, namely trying to reveal information related to the aspects of the counselee's feelings but produce very great different answers. The first question is a closed question that requires a "yes or no" answer, although the counselee may choose to elaborate on the answer, most counselees choose not to, while the second question is an open question that requires a relatively rich answer. The open-ended questions that can be used by the counselor in the counseling process can be started with the question "what, who, where, when, why, and how". The types of questions that will be used later depending on the orientation of the counselor and the goals to be achieved in the counseling process. ${ }^{32}$

Although it is a very important skill, in fact using open-ended questions is often described as one of the most difficult skills. Most said that they could easily compile and use open-ended questions in everyday life, but not in the counseling process (this information was obtained based on a preliminary study that had previously been carried out on fourthsemester students of Guidance and Counseling Program, Faculty of Tarbiyah and Teacher Training, State Islamic Institute of Bukittinggi. As a result, instead of using openended questions, prospective counselors prefer to use closed-ended questions or as much as possible avoid using open-ended questions for a fear of making errors. Based on this information, it should be necessary to take immediate action, especially in revealing

$$
32 \text { Yeo, p. } 1 .
$$


further information about student difficulties in using these open-ended questions.

This research aimed to reveal the openended questions that students asking in the individual counseling process and the errors behind it. Further efforts can be carried out as a follow-up to information regarding the misuse of open-ended questions revealed through this research.

\section{Method}

This research is a quantitative descriptive study. In this study, 27 students of Semester IV Guidance and Counseling Program, Faculty of Tarbiyah and Teacher Training, State Islamic Institute of Bukittinggi in the academic year 2019/2020 were involved as research samples. The sampling technique used was total sampling. The data were obtained through video recordings and counseling scenarios and analyzed using simple descriptive statistics. The information was analyzed in two ways; firstly analyzing the student counseling video recordings, and secondly analyzing the counseling scenarios made by students.

\section{Finding and Discussion}

\section{Finding}

Through analyzing videos and counseling scenarios and comparing to the theoretical literature of using open-ended question during the counseling process, the following types of error were found when students used open-ended questions

Table 1: Classification of Open Question Usage Errors

\begin{tabular}{llcc}
\hline No & \multicolumn{1}{c}{ Types of error } & f & $\%$ \\
\hline 1 & $\begin{array}{l}\text { Using open-ended } \\
\text { questions that are not } \\
\text { coherent }\end{array}$ & 19 & 70,37 \\
\hline 2 & $\begin{array}{l}\text { Using open-ended } \\
\text { question "why" }\end{array}$ & 18 & 66 \\
\hline 3 & $\begin{array}{l}\text { Using repeated open- } \\
\text { ended questions that } \\
\text { have the same meaning }\end{array}$ & 11 & 40,74 \\
\hline 4 & $\begin{array}{l}\text { Using open-ended } \\
\text { question which is not in }\end{array}$ & 8 & 29,62
\end{tabular}

\begin{tabular}{lllc}
\hline No & \multicolumn{1}{c}{ Types of error } & f & \% \\
\hline 5 & line with the context & & \\
\hline & Other types of errors: & & 14,81 \\
\hline $\begin{array}{l}\text { a. Using open-tailed } \\
\text { questions }\end{array}$ & 4 & 11,11 \\
& $\begin{array}{l}\text { b. } \\
\text { questions } \\
\text { simultaneously at the } \\
\text { same time }\end{array}$ & 3 & 11,11 \\
& $\begin{array}{l}\text { c. do not openly } \\
\text { question at all }\end{array}$ & 3 & \\
$* A$ single sample can make more than one error &
\end{tabular}

Table 1 above shows the errors in using open-ended questions made by 27 Semester IV Guidance and Counseling Program, Faculty of Tarbiyah and Teacher Training, State Islamic Institute of Bukittinggi in the academic year 2019/2020 during the individual counseling process.

\section{Discussion}

This research is intended to identify the mistakes made by the students of the Guidance and Counseling Program, Faculty of Tarbiyah and Teachers Training, State Islamic Institute of Bukittinggi in using open-ended questions, especially in the individual counseling process. 27 total students are involved in this research to obtain answers to these research questions. The results indicated that there are 7 (seven) common mistakes made by students in using open-ended questions in the individual counseling process

First is the use of open-ended questions that are not coherent. Open-ended questions are often juxtaposed with wrinkles. The wrinkling simply means not skipping. It means that there is a connection between the first question and the next. Moreover, the counselor is said to be coherent when the counselor discusses the "B" aspect after the "A" aspect, discusses the "C" aspect after the "B" aspect, and so on. With conciseness, even open-ended questions that are appropriate but not used coherently will not produce the desired effect of using open-ended questions. Unfortunately, this error is the most common 
error made by students; it was $70.37 \%$. The use of open questions that are not coherent can be seen in the following section of the counseling transcript:

Counselor: coba ceritakan apa yang mengganggu pikiran dan perasaan kamu saat ini (please tell me, what is bothering you with your mind and feelings right now)

Counselee: begini bu, akhir-akhir ini saya merasa kesulitan berkonsentrasi (hhmm, lately I find it difficult to concentrate)

Counselor: coba ceritakan lebih lanjut (please tell us more)

Counselee: begini bu, biasanya saya termasuk orang yang mudah berkonsentrasi babkan pada saat kelas tidak kondusif sekalipun. Jika ada teman-teman yang mengobrol ketika guru menerangkanpun, saya tetap bisa menyimak penjelasan guru dengan cukup baik. Tetapi sekarang, meskipun kelas sedang tenang, saya tetap sulit memusatkan perbatian saya (I am usually easy to concentrate even when class is not conducive. Even if there are friends who chat when the teacher explains, I still can listen to the teacher's explanation quite well. But now, even though the class is quiet, I found it difficult to pay attention to the lesson)

Counselor: sejak kapan tepatnya kamu mengalami gangguan berkonsentrasi tersebut? (When exactly did you start experience this concentration disorder?)

Counselee: hmm....kira-kira sejak 2 minggu yang lalu bu (konseli mengerutkan kening dan terlibat berpikir). ( $\mathrm{hmm}$.... about 2 weeks ago ma'am (counselee frowns and looks thinking)

Counselor: apa sebetulnya yang terjadi sehingga kamu sulit berkonsentrasi? (What exactly happened to you that make it difficult for you to concentrate?)

Counselee: bagaimana ya bu menceritakannya (konseli menggaruk bagian belakang kepalanya pada saat mengungkapkan ini). Mungkin saya sedikit kepikiran orang tua saya yang sering bertengkar belakangan ini. Kalau sedang berkumpul dengan teman-teman, saya malah tidak terlalu terbawa pikiran, tetapi pada saat situasi sangat tenang di jam pelajaran, saya malah memikirkannya. (how should I tell it) (counselee scratches the back of his head at the time of disclosing this). Maybe I am a little concerned about my parents who have been fighting a lot lately. When hanging out with my friends, I don't even get carried away, but when things are very calm during class hours, I even think about it Counselor: o begitu...lalu apa yang kamu inginkan sekarang? (I see... then what do you want now?)

Counselee: Saya ingin kembali lagi seperti dulu bu (I want to go back to how it used to be, ma'am)

Counselor: Apa yang bisa kamu lakukan untuk mewujudkan hal tersebut? (what can you do to make this happen)

Counselee: hmmm... Saya bingung bu,, Apa yang harus saya lakukan ya bu? (hmm... I'm confused ma'am ... what should I do, ma'am)

Counselor: baik, sekarang coba ceritakan dulu, bagaimana tanggapan guru pada saat kamu terlibat kesulitan berkonsentrasi? (Ok, now try to tell me first, how does the teacher respond when you seem to have trouble concentrating)

In the section of the counseling transcript above, it can be seen that up to the question "what actually happened", there are still no problems related to the sequence of open questions used by the counselor, but on the question "what do you want now", a sequence of questions used by the counselor began to appear. The "what do you want" question should only be used by the counselor at the coaching stage (nearing the end of the counseling process), as well as the question, 
"what can you do to make this happen". Ideally, after the counselee has explained the answer to the counselor's question about "what actually happened to make it difficult for you to concentrate?, the counselor should explore the information disclosed by the counselee on the answer to the counselor's question first. The counselor's indecisiveness was seen again when using the question "how does the teacher respond when you seem to have difficulty concentrating". By using this question, the counselor seems to return to the initial discussion related to the counselee's problem. You can imagine the end of the counseling process with back-and-forth questions posed to the counselee

The second is the use of open-ended questions with the word question" why". The use of open-ended questions with the question "why" could be highly discouraged in the counseling process. ${ }^{33}$ Instead of getting indepth and broad information from the counselee, the use of "why" indirectly leads the counselee to seek "legality" and "rationality" for his inappropriate behavior. In other words, the question "why" produces such answers which often justify the counselee's behavior. ${ }^{34}$ Besides, it is also suggested not to use the why question too often, because why questions tend to lead to prolonged discussions about the past. ${ }^{35}$ This error was committed by $66 \%$ of students. The use of open-ended questions with the question, "why can be seen in the following section of the counseling transcript:

Counselor: apa yang dapat kita bicarakan hari ini? (what is our topic today?) Counselee: begini bu....saya punya masalah dengan teman satu kos saya bu (I see....I

33 Geldard and Geldard, Keterampilan Praktik Konseling (Eva Hamdiah: Terj) (Yogyakarta: Pustaka Pelajar, 2011), p. 41.

34 Arif Ainur Rofiq, Teori Dan Praktik Konseling (Surabaya: Raziev Jaya, 2017), p. 1.

${ }^{35}$ Yeo, p. 1. have a problem with my roommate ma'am)

Konselor: ya....coba ceritakan lebih lanjut (yes .... try to tell more please)

Counselee: saya kan tinggal sekamar dengan teman di kos dekat-dekat sini bu. Awalnya satu kamar itu cuma ada tiga orang saja. Kemudian bulan lalu ada pengbuni baru (konseli berhenti berbicara dan melihat konselor) (I live in a room with a friend in a boarding house near here, ma'am. Initially there were only three people in one room. Then, last month there are new residents (the counselee stops talking and sees the counselor)

Counselor: ya terus... (yes ...and then)

Counselee: awalnya ketika kami tinggal bertiga nyaris tidak ada masalah di kos tersebut. Setelah ada penghuni baru, kos rasanya tidak nyaman saja, rasanya ada sesuatu yang berbeda. Awal masalabnya bermula Minggu lalu. Saya menyampaikan kepada teman baru tersebut babwa setiap penghuni kos wajib piket dua kali seminggu. Eh...dia langsung marah (konseli memperlihatkan mimik muka tidak suka) (Initially there was almost no problem in the boarding house when the three of us lived. After new resident came, the boarding house seems look uncomfortable; it feels like something is different. The problem started last Sunday. I told to this new friend that every resident of the boarding house must clean the boarding house twice a week. She immediately got angry (the counselee showed a dislike of her face)

Counselor: Bagaimana cara kamu menyampaikan informasi tentang tugas piket tersebut kepadanya? (How do you convey information about cleaning the boarding house as an assignment to her?

Counselee: ya...saya sampaikan seperti biasa saja bu. Waktu itu dia pulang entab dari mana. Saya bilang jadwal piket dia Hari 
Selasa dan Kamis. Eh dia langsung marahmarah dan bilang bahwa dia tidak bisa. Dia sangat sibuk di hari Selasa dan Kamis, dia tidak perlu diingat-ingatkean seperti itu, dan bahwa saya tidak berbak mengatur-ngatur dia. Katanya dia bayar juga di kos tersebut. Saya membencinya bu, dan semakin membencinya dari hari ke hari (konseli meninggikan suara). Saya ingin dia keluar saja dari kos tersebut. (I say as usual, ma'am. At that time she came home from nowhere, I told her that her schedule is on Tuesday and Thursday. She immediately got angry and said that she could not do this task. She's very busy on Tuesdays and Thursdays, she doesn't need any reminders like that, and then she said that I have no right to mess with her. She said that she also paid some amount of money to stay at the boarding house. I hated her mom, and I hate her more everyday (counselee raises voice). I want her getting out of the boarding house.)

Counselor: mengapa kamu membencinya dan berharap dia keluar? (why do you want to hate her and wish her to leave the boarding house?

Counselee: Jelas saja saya benci bu, dia penghuni baru barusnya dia yang menyesuaikan diri dengan penghuni lama, bukan kami pula yang mengikuti dia. Lagian kalaupun memang tidak bisa,,sampaikan dengan cara baik-baik, bukan marah-marah seperti itu. Dia pikir dia siapa. Dia sepertinya juga tidak ada niat untuk baik-baik dengan penghuni kos yang lain oleh karena itu saya ingin dia keluar saja. (Obviously I hate her ma'am ... she is a new resident, she should be the one who adjusts to the old residents, it is not us who follow her Besides, even if she can't ... she shouldn't be angry like that. Who does she thinks she is? She also seemed to have no intention of getting along with the other residents of the boarding house so I wanted her to just leave)

In the transcript of the above counseling, it can be seen that the use of open-ended questions with the question "why do you hate her and expect her to leave"? Seems to provoke the counselee to seek justification for her attitude and behavior. In the above case, hating other people seemed to like the truth, because according to the counselee, someone deserves to be hated. Of course, things like this are not expected by any counselor in the counseling process.

The third is the use of open-ended questions that are repeated or have the same meaning. This often happens when the counselor "runs out" of questions to use. The result is a single rounded question. Thus, the information obtained was not as detailed as expected. For example, what were you doing at that time? How did you respond at that time? These two questions are relatively the same but are often used after asking the other. Unfortunately, counselors often do not realize they have made this type of error. This error was made by $40.74 \%$ of students.

The fourth is an open-ended question that does not in line with the context. The counselor's confusion in thinking about openended questions used often results from many open-ended questions that are not in line with the context. Despair in continuing the counseling process when the "stock" of openended questions is running out, often leads to the use of "reckless" open-ended questions like these. It may cause changes in the direction and focus of the discussion in the counseling process. However, the focus of the discussion in the counseling process is none other than the counselee. Questions that are not in line with this context are classified as extremely ineffective questions according to the scale of the questioning effectiveness of 
the Scalare model. ${ }^{36}$ This error was made by $29.62 \%$ of students. The use of open-ended questions that do not fit the context can be seen in the following counseling transcript:

Counselor: apa yang bisa ibu bantu? (What can I do for you?)

Counselee: hehe....saya sedang ada masalah bu (konseli berbicara sambil menunjukan ekespresi babwa ia malu) (hehe .... I have a problem ma'am (the counselee speaks while showing an expression that she is embarrassed))

Counselor: ya.....coba ceritakan lebib lanjut agar ibu bisa memahaminya,,,tidak perlu sungkan...ceritakan saja semuanya secara terbuka (yes...try to tell me further so that $i$ can understand it...no need to hesitate... just tell everything openly) Counselee: begini bu...saya punya teman dekat,,,pria bu (masib malu-malu mempermainkan jari jemarinya dan kemudian melihat kepada konselor) (Look, ma'am ... I have a close friend ...a man, ma'am (still shy, playing with her fingers and then looking at the counselor)

Counselor: ya...terus... (yes...)

Counselee: teman dekat saya tadi usianya jaub melebibi saya bu. Setelah tamat dari sekolah ini, teman dekat ini mengajak saya menikah. Saya sebetulnya mau bu, tapi.... (konseli menghentikan pembicaraan dan melihat kepada konselor) (My close friend is much older than me, ma'am. After graduating from this school, he asked me to get married. I actually want to do it mom, but... (counselee stops talking and looks at the counselor)

Counselor: ya...tapi???apa yang mengganggu pikiranmu? (yes....but? what's bothering you?)

36 Gerald Sklare, Pedro Portes, And Howard Splete, 'Developing Questioning Effectiveness in Counseling', Counselor Education and Supervision, 25.1 (1985), p.12-20 <https://doi.org/10.1002/j.15566978.1985.tb00507.x>.
Counselee: di kampung saya, memang banyak yang menikah muda tetapi saya masib punya kakake perempuan yang belum menikah sehingga rasanya segan untuk menikah terlebih dahulu. (In my village, many couples are married young but I still have older sisters who are not married so I feel reluctant to get married first)

Counselor: Bagaimana sebetulnya pandangan masyarakat tentang menikah muda ini? (How do people actually view marrying young?)

Counselee: masyarakat tidak mempermasalabkan bu, soalnya banyak juga yang menikah muda. Masalahnya, kakake saya ini bu...kakak saja belum menikah sementara saya sudah mau menikah. (The community does not make a problem ma'am, because many of them are married young. The problem is, my sister is ... my sister is still single while I am already planning to get married)

Counselor: Lalu bagaimana reaksi teman pria kamu? Then how did he react?

The counselor's question about how the above community views actually do not match the problems described by the counselee. The counselee's problem is not related to the community's view of marrying young, but rather to the counselee's feeling of reluctance to his sister. It is clear that the counselor uses open-ended questions that do not fit the context, in this case, it is not in accordance with the subject matter experienced by the counselee.

The fifth is the use of open-tailed questions. "Apa yang kamu rasakan waktu itu" ("What did you feel at that time"?). "saya sedib bu" (I am sad ma'am), "sedih seperti apa yang kamu maksud?" ("sad like what do you mean?"), 'sedih karena tidak ada yang menghargai usaha yang saya lakukan", (Sad because no one appreciates the effort I did), "tidak menghargai usaha seperti apa yang kamu maksud?" ("does not 
appreciate the kind of effort you mean"?), and so on. This simple example shows that the counselor only pays attention to the end of the counselee's sentence and then arranges the question from the end of the counselee's sentence. The open-ended questions used in the counseling process must not such a kind of these open-tailed questions. At least $14.81 \%$ of students made errors like this.

The sixth is to use 2 (two) open-ended questions at the same time, "Bagaimana reaksimu waktu itu dan bagaimana pula perasaaan kamu?", ("How did you react at that time and how did you feel?"), "Apa yang kamu sampaikan pada ayabmu waktu itu dan bagaimana kamu menyampaikannya", ("What did you tell your father at that time and how did you convey it?"). In this case, the counselors use 2 questions at the same time. This is certainly not recommended in counseling. Basically, the counselor must speak less than his client, as well as when asking questions. It is not advisable to bombard a client with multiple questions at once. ${ }^{3738} \mathrm{It}$ is said that "good question askers only ask one question at a time and don't have to explain their questions". ${ }^{39}$ The use of multiple questions like this is classified as ineffective according to the scale of the questioning effectiveness of the Scalare model 40 This type of error was committed by $11,11 \%$ of students.

The seventh is not using open-ended questions at all. $11.11 \%$ of students did it. They either did not use open-ended questions in counseling or at all knew that they did not use open-ended questions. In general, students who do this actually do not even use

${ }^{37}$ Susan R. Davis Scott T. Meier, The Elements of Counseling, Eighth Edi (USA: Waveland Press, 2019), p. 1.

38 Sunera M Fernando, "Communication Skills and Counselling," Sri Lanka Journal of Obstetrics and Gynaecology, 34.2 (2012), p. 69 $<$ https://doi.org/10.4038/sljog.v34i2.4832>.

${ }^{39}$ Borck, p. 1.

${ }^{40}$ Sklare, Portes, and Splete, p. 12-20. interrogative sentences, but only express sentences that are expressed in a questioning tone or with a question mark at the end of the sentence. Anda sedih? (Are you sad?), Anda melakukannya? (you do it?).

The ability to use open-ended questions to obtain detailed, extensive, and indepth information about the counselee as mentioned above is certainly desirable for the counselor. Counselors need to be highly skilled at using these open-ended questions. However, many counselors still have difficulty using open-ended questions. This is proven through the many errors made by the counselor when using open-ended questions. As seen in Table 1, there are at least several types of misuse of open-ended questions that have been revealed through this research.

Open-ended questions provide the counselee with a broad space to explore himself and encourage the counselee to express his thoughts and feelings more freely. If the counselor asks, "did you feel good today", then the answer is either "yes or no". However, if the counselor asks, "how are you feeling today", the answers given by the counselee can be more varied. Besides, using appropriate open-ended questions, the counselor can receive answers that are even completely unexpected. "How is your family? The counselor may in this case only expect answers in the form of the number of children or the number of family members, but the counselee can answer by saying that his family is a very happy family, with two children and two cute grandchildren and a very cute Persian cat. Of course, this information was completely unexpected by the counselor.

In its history, open-ended questions have been used in a variety of work and counseling approaches. One of them is the use of open-ended questions in pharmacist counseling. In pharmacist counseling, it was found that using an open-ended question in 
asking patients concerning how they use their medicines has been more efficient to increase the use of proper medicines for them. ${ }^{41}$ Not only that, but pastoral counseling has also proven it. It is said that the most important thing in pastoral counseling is to listen to the counselee carefully while the counselor is also advised to be able to well-understand the use of open-ended questions in counseling. ${ }^{42}$

\section{Conclusion}

There are seven common errors students make in using open-ended questions during counseling. These errors are using open-ended questions that are not coherent, using open-ended questions "why", using repeated open-ended questions, using question sentences that are not in line with the context, using open-tailed questions, using 2 (two) open-ended questions at a time, and not using open-ended questions at all.

The misuses of open-ended questions revealed in this study certainly need immediate intervention. It is recommended that future researchers use appropriate interventions to help minimize errors in using open-ended questions in the counseling process

\section{References}

\section{Book}

Aldridge, Sally, and Sally Rigby, 'Counselling Skills in Context' (London: British Library Cataloguing. 2001)

Allen E. Ivey, Mary Bradford Ivey, Carlos P. Zalaquet, Intentional Interviewing and Counseling: Facilitating Client Development in

41 A. Ekedahl, “'Open-Ended Questions' and 'Show-and-Tell'-a Way to Improve Pharmacist Counselling and Patients' Handling of Their Medicines," Journal of Clinical Pharmacy and Therapeutics, 21.2 (1996), p.95-99 <https://doi.org/10.1111/j.13652710.1996.tb00007.x>.

${ }^{42}$ G.E. Boyd, "Pastoral Conversation: Relational Listening and Open-Ended Questions," Pastoral Psychology, $51 \quad$ (2003), $\quad$ p.345-360 $<$ https://doi.org/https://doi.org/10.1023/A:10236140 $30428>$. a Multicultural Society, 9th edn (Cengage Learning, 2013)

Borck, Lesli E, Learning Counseling and Problem Solving Skilss (Newyork: The Haworth Press, 1982)

Cavaco, Afonso, 'Pharmaceutical Care and Patient Counseling, in The Pharmacist Guide to Implementing Pharmacentical Care (Cham: Springer International Publishing, 2019), pp. 33-40 $<$ https://doi.org/10.1007/978-3-31992576-9_4>

Colledge. Ray, Mastering Counseling Theory (Newyork: Palgrave Macmillan, 2002)

Cormier, Interviewing and Change Strategies for Helpers: Fundamentals Skills and Cognitive Behavioral Interventions (California: Brooks/ Cole, 2009)

Geldard and Geldard, Keterampilan Praktik Konseling (Eva Hamdiab: Terj) (Yogyakarta: Pustaka Pelajar, 2011)

Gibson and Mitchell, Bimbingan Dan Konseling (Yudi Santoso: Terj). (Yogyakarta: Pustaka Pelajar, 2011)

Hugh Crago, Penny Gardner, A Safe Place for Change, Revised 2nd Edition: Skills and Capacities for Counseling and Therapy, revised 2n (Australia: Australia: Digital Publishing Centre an Imprinting Interactive Publication Brisbane, 2019)

March-Smith, Rosie, Counselling Skills for Complementary Therapists, (New York: Open University Press. 2005)

Rofiq, Arif Ainur, Teori Dan Praktik Konseling (Surabaya: Raziev Jaya, 2017)

Scott T. Meier, Susan R. Davis, The Elements of Counseling, Eighth Edi (USA: Waveland Press, 2019)

Yeo, Anthony, Konseling: Suatu Pendekatan Pemecahan Masalah (Antonius Wuisan, Teri) (Jakarta: Gunung Mulia, 2007)

Yusuf, Syamsu, 'Karakteristik, Kompetensi Dan Peran Konselor', 2020

\section{Journal}

AbuSabha, Rayane, 'Interviewing Clients and 
Patients: Improving the Skill of Asking Open-Ended Questions', Journal of the Academy of Nutrition and Dietetics, 113 (2013), p.624-633 https://doi.org/10.1016/j.jand.2013.01.0 $\underline{02}$

Bakkar, B. S. (2012). The Effect of a Counseling Microskills Course on the Mastery Level of Communication Skills among Omani Career Counselors. Philippine Journal of Counseling Psychology, 14(1), p.44-56

Boyd, G.E., 'Pastoral Conversation: Relational Listening and Open-Ended Questions', Pastoral Psychology, 51 (2003), p.345-360 https://doi.org/https://doi.org/10.1023 LA:1023614030428

Ekedahl, A., “'Open-Ended Questions” and 'Show-and-Tell'-a Way to Improve Pharmacist Counselling and Patients' Handling of Their Medicines', Journal of Clinical Pharmacy and Therapeutics, 21.2 (1996), p. 95-99 https://doi.org/10.1111/j.13652710.1996.tb00007.x

ErlinaYaumas, Nova, Syafrimen Syafril, Norhayati Mohd Noor, Zuria Mahmud, Jusnimar Umar, Ismail Wekke, and others, 'The Importance of Counselling Basic Skills for the Counsellors', International Journal of Pure and Applied Mathematics, 119 (2018), p.1195-1207

Fernando, Sunera M, 'Communication Skills and Counselling', Sri Lanka Journal of Obstetrics and Gynaecology, 34.2 (2012), 69 https://doi.org/10.4038/sljog.v34i2.483 $\underline{2}$

Hill, Clara E., Melissa Roffman, Jessica Stahl, Suzanne Friedman, Ann Hummel, and Chrisanthy Wallace, 'Helping Skills Training for Undergraduates: Outcomes and Prediction of Outcomes.', Journal of Counseling Psychology, 55 (2008), p.359-370 https://doi.org/10.1037/0022-

$\underline{0167.55 .3 .359}$

James, Ian Andrew, Rachel Morse, and Alan Howarth, 'The Science and Art of Asking Questions in Cognitive Therapy',
Behavioural and Cognitive Psychotherapy, 38 (2010),

https://doi.org/10.1017/S135246580999 $\underline{049 X}$

Koltz, Rebecca L., and Stephen S. Feit, 'A Phenomenological Study: The Experience of Live Supervision during a Pre-Practicum Counseling Techniques Course', Qualitative Report, 17 (2012), p.124

Larussi, Melanie M, Jesssica M Tyler, J M Crawford, and S H Crawford, 'Outcomes of Incorporating Motivational Interviewing into Basic Counselor Skills Training, The Journal of Counselor Preparation and Supervision, 12 (2019) https://repository.wcsu.edu/jcps/vol12/ iss1/4

McCarthy Veach, Patricia, Bonnie S. LeRoy, and Nancy P. Callanan, 'Gathering Information: Asking Questions', in Facilitating the Genetic Counseling Process (Cham: Springer International Publishing, 2018), pp. 111-37 https://doi.org/10.1007/978-3-31974799-6 5

Pérez-Rosas, Verónica, Xuetong Sun, Christy Li, Yuchen Wang, Kenneth Resnicow, and Rada Mihalcea, 'Analyzing the Quality of Counseling Conversations: The Tell-Tale Signs of High-Quality Counseling, in LREC 2018 - 11th International Conference on Language Resources and Evaluation, 2019, pp. 3742-48

Rautalinko, Erik, 'Reflective Listening and Open-Ended Questions in Counselling: Preferences Moderated by Social Skills and Cognitive Ability', Counselling and Psychotherapy Research, 13 (2013), 24-31 https://doi.org/10.1080/14733145.2012. $\underline{687387}$

Ridley, C. R., Kelly, S. M., \& Mollen, D., 'Microskills Training: Evolution, Reexamination, and Call for Reform', The Counseling Psychologist, 39 (2011), p.800824

https://doi.org/https://journals.sagepub .com/doi/10.1177/0011000010378438 
Setiyowati, Arbin Janu, Marthen Pali, Bambang Budi Wiyono, and Triyono Triyono, 'Structural Model of Counseling Competence', Cakrawala Pendidikan, 38 (2019), p. $45-62$ https://doi.org/10.21831/cp.v38i1.2150 $\underline{9}$

Sklare, Gerald, Pedro Portes, And Howard Splete, 'Developing Questioning Effectiveness in Counseling', Counselor Education and Supervision, 25.1 (1985), p.12-20 https://doi.org/10.1002/j.15566978.1985.tb00507.x

Tanana, Michael J., Christina S. Soma, Vivek Srikumar, David C. Atkins, and Zac E. Imel, 'Development and Evaluation of Clientbot: Patient-like Conversational Agent to Train Basic Counseling Skills, Journal of Medical Internet Research, p.21 (2019) https://doi.org/10.2196/12529
Evans, D, M Hearn, and M Uhlemann, 'Counselling Micro Skills', Essential Interviewing: A Programmed Approach to Effective Communication, 1998, p.156 - 157

Muhammad, Syed, and Sajjad Kabir, 'Topics Covered Active Listening Verbal and Non-Verbal Messages Attending Responding Paraphrasing Summarizing Ask Questions Probing', March 2017, 2018

Wozny, Darren A, and Joshua C Watson, 'Counselors' Questioning Skills Repertoire: What We Use and What We Don't.', VISTAS Online, 2006, p.139-42 http://www.counseling.org/docs/default -source/vistas/counselors-questioningskills-repertoire-what-we-use-and-whatwe-dont.pdf?sfvrsn $=10$

\section{Internet Sources}

Drab, Kevin J, 'The Top Ten Basic Counseling Skills', 1, 2015, 1-3 https://www.people.vcu.edu/ krhall/re sources/cnslskills.pdf 